Indonesian Journal of Development Economics http: journal.unnes.ac.id/sju/index.php/efficient

\title{
Pengaruh Investasi, Laju Pertumbuhan Ekonomi, dan Upah Terhadap Penyerapan Tenaga Kerja
}

\author{
Wildan \\ Jurusan Ekonomi Pembangunan,Fakultas Ekonomi, Universitas Negeri Semarang \\ Permalink/DOI: https://doi.org/10.15294/efficient.vii3.27878
}

Received: April 2018; Accepted: July 2018; Published: October 2018

\begin{abstract}
This study aims to Influence Investment, Economic Growth Rate, and Wages Against Absorption of Employment in Bogor Regency with the research method used in this study is a quantitative descriptive research method. The data used are secondary data which are analyzed by the quantitative method of multiple linear regression using the Ordinary Least Square (OLS) method. While the model used in this study is a model of the employment absorption function with 3 independent variables and 1 dependent variable. Based on the results of processed data using regression regarding the effect of investment, the rate of economic growth, and wages on labor absorption in Bogor Regency, it can be concluded that investment does not have a significant effect on employment in Bogor Regency. The economic growth rate has a positive and significant effect on employment in Bogor Regency. Wages have a positive and significant effect on employment in Bogor Regency. Simultaneously investment, economic growth rate, and wages show a significant influence on employment in Bogor Regency.
\end{abstract}

Keywords: Investment, Economic Growth Rate, and Wages Against Quantitative Labor Absorption, multiple linear regression, simultaneous

\begin{abstract}
Abstrak
Penelitian ini bertujuan untuk Pengaruh Investasi, Laju Pertumbuhan Ekonomi, dan Upah Terhadap Penyerapan Tanaga Kerja di Kabupaten Bogor dengan metode penelitian yang dipakai dalam penelitian ini adalah metode penelitian deskriptif kuantitatif. Data yang digunakan adalah data sekunder yang dianalisis dengan metode kuantitatif regresi linear berganda dengan metode Ordinary Least Square (OLS). Sedangkan Model yang digunakan dalam penelitian ini adalah model fungsi penyerapan tenaga kerja dengan 3 variabel independen dan 1 variabel dependen. Berdasarkan hasil data yang telah diolah menggunakan regresi mengenai pengaruh investasi, laju pertumbuhan ekonomi, dan upah terhadap penyerapan tenaga kerja di Kabupaten Bogor, dapat ditarik kesimpulan bahwa investasi tidak berpengaruh signifikan terhadap penyerapan tenaga kerja di Kabupaten Bogor. Laju pertumbuhan ekonomi berpengaruh positif dan signifikan terhadap penyerapan tenaga kerja di Kabupaten Bogor. Upah berpengaruh positif dan signifikan terhadap penyerapan tenaga kerja di Kabupaten Bogor. Secara simultan investasi, laju pertumbuhan ekonomi, dan upah menunjukkan pengaruh yang signifikan terhadap penyerapan tenaga kerja di Kabupaten Bogor.
\end{abstract}

Kata Kunci: Investasi, Laju Pertumbuhan Ekonomi, dan Upah Terhadap Penyerapan Tanaga Kerja kuantitatif, regresi linear berganda , simulta

How to Cite: Wildan, W. (2018). Pengaruh Investasi, Laju Pertumbuhan Ekonomi, dan Upah Terhadap Penyerapan Tenaga Kerja. EFFICIENT Indonesian Journal of Development Economics, 1(3), 200-206. https://doi.org/10.15294/efficient.vii3.27878

(C) 2018 Semarang State University. All rights reserved

\footnotetext{
Alamat Korespondensi :

Alamat: Gedung L2 Lantai 2 FE Unnes

Kampus Sekaran, Gunungpati, Semarang, 50229

E-mail : efficientjournal@gmail.com
}

ISSN 


\section{PENDAHULUAN}

Salah satu tolak ukur dalam menentukan keberhasilan pembangunan ekonomi adalah pertumbuhan ekonomi, yang menggambarkan suatu dampak nyata dari kebijakan pembangunan yang dilaksanakan. Pertumbuhan ekonomi berkaitan erat dengan proses peningkatan produksi barang dan jasa dalam kegiatan ekonomi masyarakat. Menurut Djojohadikusumo (1993) dalam pertumbuhan ekonomi biasanya ditelaah proses produksi yang melibatkan sejumlah jenis produk dengan menggunakan sarana dan prasarana produksi. Dalam memproduksi barang dan jasa yang merupakan output dari suatu produksi, diperlukan input yang maksimal.

Mengingat jumlah pengangguran yang cukup tinggi dan didukung banyaknya penduduk di Indonesia yang utamanya di Provinsi Jawa Barat menjadi provinsi dengan penduduk terbanyak di Indonesia, sehingga masalah tenaga kerja seperti pengangguran mungkin saja terjadi. Faktor utama yang menimbulkan pengangguran adalah kekurangan pengeluaran agregat. Para pengusaha memproduksi barang dan jasa dengan maksud memperoleh keuntungan. Keuntungan tersebut akan mereka dapat bilamana pengusaha berhasil menjual barang dan jasa yang mereka jual. Ini ada hubungannya dengan tingkat penyerapan tenaga kerja, dimana semakin banyak barang yang diproduksi akan semakin meningkatkan jumlah permintaan tenaga kerja di masyarakat (Sukirno, 2002). Tabel 1. menjelaskan jumlah penduduk Kabupaten Bogor masuk dalam 5 Kabupaten dengan penduduk tertinggi di Provinsi Jawa Barat. Dengan penyerapan tenaga kerja sebesar 14,5\% menjadi perhatian bila melihat jumlah penduduk Kabupaten Bogor yang menjadi jumlah penduduk tertinggi di Provinsi Jawa Barat itu sendiri.

Tabel 2. menjelaskan jumlah penanaman modal secara keseluruhan ditiap tahunnya berbeda - beda. Tahun 2010 hingga kepada tahun 2014 jumlah penanaman modal meningkat tiap tahunnya. Mulai sebesar 1.428,62 milliar rupiah pada tahun 2010, naik menjadi 3.475,79 milliar rupiah ditahun 2011. Begitu juga tahun 2012 pada tahun 2013 naik dari 2.411,32 milliar rupiah menjadi 8.214,85 milliar rupiah dan diikuti peningkatan penyerapan tenaga kerja sebanyak 27.174 orang pekerja yang terserap. Berlanjut pada tahun 2014 dengan angka penanaman modal di Kabupaten Bogor naik menjadi sebesar 12.931,22 milliar rupiah. Namun, peningkatan itu tidak diimbangi dengan peningkatan jumlah tenaga kerja yang terserap. Karena, hanya sebanyak 28.057 pekerja yang terserap dan itu menjadi lebih sedikit dibanding tahun sebelumya yaitu sebanyak 39.250 orang. Tahun 2015 penanaman modal turun menjadi 7.987,56 milliar rupiah dengan penyerapan tenaga kerja sebanyak 19.453 orang pekerja.

Seperti yang terlihat pada gambar. 1 berikut ialah pada tahun 2011 upah di Kabupaten Bogor sebesar Rp.1,172 juta yang meningkat menjadi Rp.1,269 ditahun 2012. Kemudian di tahun 2013 kembali meningkat menjadi Rp.1,804 juta. Tahun 2014 dan ditahun 2015 upah pekerja di Kabupaten Bogor masing - masing meningkat sebesar Rp.2,242 juta dan Rp.2,590 juta. Berikut grafik perkembangan upah di Kabupaten Bogor tahun 2011 hingga 2015 pada Gambar 1. 
Tabel 1. Jumlah 5 Kabupaten/Kota dengan Penduduk Tertinggi di Provinsi Jawa Barat Tahun 2011 - 2015

\begin{tabular}{lllllll}
\hline No & Kabupaten/Kota & 2011 & 2012 & 2013 & 2014 & 2015 \\
\hline 1 & Kab. Bogor & 4.922 .205 & 4.989 .939 & 5.111 .769 & 5.331 .149 & 5.459 .668 \\
2 & Kab. Bandung & 3.235 .615 & 3.351 .048 & 3.405 .475 & 3.470 .393 & 3.534 .114 \\
3 & Kab. Bekasi & 2.677 .631 & 2.912 .499 & 3.002 .112 & 3.122 .698 & 3.246 .013 \\
4 & Kab. Garut & $\mathbf{2 . 4 4 5 . 9 1 1}$ & $\mathbf{2 . 4 8 5 . 7 3 2}$ & $\mathbf{2 . 5 2 5 . 4 8 3}$ & $\mathbf{2 . 5 2 6 . 1 8 6}$ & $\mathbf{2 . 5 4 8 . 7 2 3}$ \\
5 & Kota Bandung & $\mathbf{2 . 4 2 4 . 9 5 7}$ & $\mathbf{2 . 4 5 5 . 5 1 7}$ & $\mathbf{2 . 4 8 3 . 9 7 7}$ & $\mathbf{2 . 4 7 0 . 8 0 2}$ & $\mathbf{2 . 4 8 1 . 4 6 9}$ \\
\hline
\end{tabular}

Sumber: Pusdalitbang Provinsi Jawa Barat, Diolah

Tabel 2. Jumlah Penanaman Modal Dalam Negeri, Penanaman Modal Asing, Total Nilai Investasi, dan Penyerapan Tenaga Kerja di Kabupaten Bogor Tahun 2010 - 2015

\begin{tabular}{|c|c|c|c|c|c|}
\hline \multirow[b]{2}{*}{ Tahun } & \multirow{2}{*}{$\begin{array}{ll}\text { Penanaman } & \text { Modal } \\
\text { Dalam Negeri } & \text { (Milliar } \\
\text { Rupiah) } & \end{array}$} & Penanaman & \multirow[b]{2}{*}{$\begin{array}{l}\text { Total Nilai Investasi } \\
\text { (Milliar Rupiah) }\end{array}$} & \multicolumn{2}{|c|}{ Penyerapan } \\
\hline & & $\begin{array}{l}\text { Modal Asing } \\
\text { (Milliar Rupiah) }\end{array}$ & & $\begin{array}{l}\text { Tenaga } \\
\text { (Orang) }\end{array}$ & Kerja \\
\hline 2010 & 460,21 & 968,41 & $1.428,62$ & 7.099 & \\
\hline 2011 & $1.733,85$ & $1.741,94$ & $3 \cdot 475,79$ & 10.839 & \\
\hline 2012 & 626,8 & $1.784,50$ & $2.411,32$ & 12.076 & \\
\hline 2013 & $2.908,90$ & $5 \cdot 312,97$ & $8.214,85$ & 39.250 & \\
\hline 2014 & $7.899,83$ & $5.031,39$ & $12.931,22$ & 28.057 & \\
\hline 2015 & $6.607,90$ & $1.379,66$ & $7 \cdot 987,56$ & 19.453 & \\
\hline Jumlah & $20.910,86$ & $17 \cdot 075,12$ & $37 \cdot 979,98$ & 116.774 & \\
\hline
\end{tabular}

Sumber: Badan Penanaman Modal dan Pelayanan Terpadu Satu Pintu, Diolah

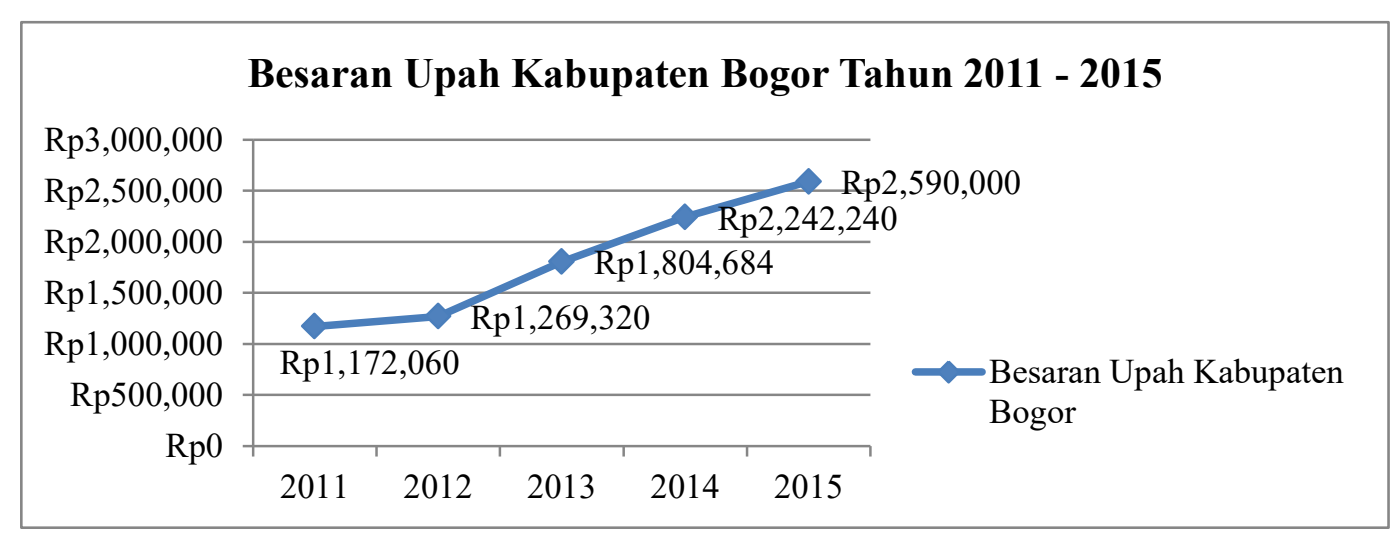

Gambar 1. Besaran Upah Minimum Kabupaten Bogor Tahun 2011 - 2015 Sumber: Sekretariat Kamar Dagang dan Industri (KADIN) Kab. Bogor, Diolah 
Gambar 2. mengenai laju pertumbuhan ekonomi di Kabupaten Bogor dari tahun 2011 hingga pada tahun 2014 yang naik di tiap tahunnya. Pada tahun 2011 angka pertumbuhan ekonomi sebesar 5,96\% naik menjadi 5,99\% ditahun 2012. Kenaikan juga terjadi ditahun 2013 sebesar 6,04\%, hingga pada tahun 2014 laju pertumbuhan ekonomi Kabupaten Bogor menjadi 6,06\%. Berikut gambar 2:

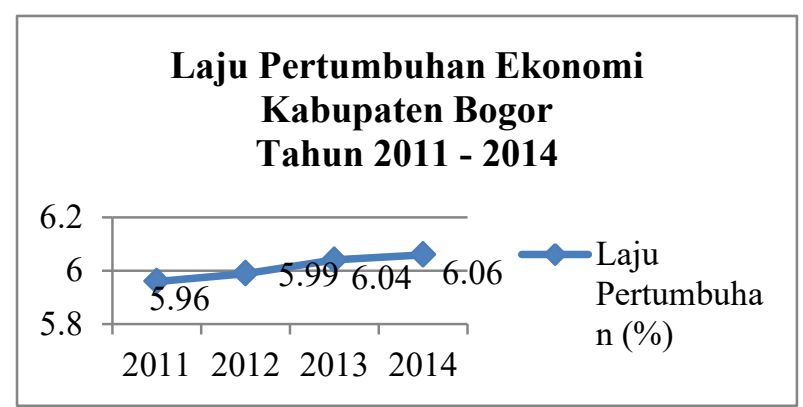

Gambar 2. Laju Pertumbuhan Ekonomi Kabupaten Bogor Tahun 2011 - 2014

Sumber: Badan Pusat Statistik (BPS) Kabupaten Bogor, Diolah

Penjelasan latar belakang mengenai Penanaman Modal Asing (PMA) dan Penanaman Modal Dalam Negeri (PMDN) di Indonesia dan Kabupaten Bogor terlihat seberapa besar jumlah modal dari tahun ke tahunnya. Kemudian, mengenai ketenagakerjaan meliputi jumlah orang bekerja serta jumlah pengangguran dan pengaruh terhadap penyerapan dari banyaknya penduduk dan investasi masuk menjadikan Kabupaten Bogor sebagai daerah yang memiliki penyerapan tenaga kerja yang kecil. Dengan penjelasan indikator yang mempengaruhi penyerapan tenaga kerja, dapat ditarik judul "Pengaruh Investasi, Laju Pertumbuhan Ekonomi, dan Upah Terhadap Penyerapan Tanaga Kerja di Kabupaten Bogor". Rumusan masalah pada penelitian ini adalah apakah ada pengaruh investasi, laju pertumbuhan ekonomi dan upah terhadap penyerapan tenaga kerja di Kabupaten Bogor secara parsial maupun simultan?

Tujuan dan penelitian ini adalah Mengetahui bagaimana pengaruh dari investasi terhadap peyerapan tenaga kerja yang ada di Kabupaten Bogor. Mengetahui pengaruh dari upah terhadap penyerapan tenaga kerja di Kabupaten Bogor. Mengetahui pengaruh laju pertumbuhan ekonomi terhadap penyerapan tenaga kerja di Kabupaten Bogor.

\section{METODE PENELITIAN}

Jenis penelitian yang digunakan adalah metode penelitian deskriptif kuantitatif. Dimulai dari pengumpulan data, pengolahan terhadap data variabel yang digunakan, serta penjelasan dari hasil data yang telah diolah. Penelitian deskriptif yaitu penelitian yang dilakukan untuk mengetahui nilai variabel mandiri, baik satu variabel atau lebih (independen) tanpa membuat perbandingan atau menghubungkan dengan variabel lain.

Data yang digunakan adalah data sekunder yang diperoleh berasal dari Badan Pusat Statistik yang ada pada lingkup nasional, provinsi, hingga kabupaten. Tidak hanya pada Badan Pusat Statistik, peneliti mendapatkan data dari Badan Penanaman Modal dan Pelayanan Satu Pintu di Kabupaten Bogor, Provinsi Jawa Barat.

Metode Analisis yang digunakan dalam penelitian ini adalah analisis kuantitatif dengan mengolah data-data yang ada sehingga dapat diperoleh hasil yang sesuai dengan tujuan penelitian. Untuk mengetahui pengaruh antara variabel independen dan variabel dependen maka dipergunakan regresi linier berganda dengan metode Ordinary 
Least Square (OLS). Dalam menghasilkan estimator OLS yang memiliki sifat BLUE (Based, Linear, Unbiased, Estimator) yaitu memenuhi asumsi klasik atau terhindar dari masalah - masalah normalitas, multikolinearitas, autokorelasi, dan heteroksedastisitas.

Metode analisis regresi linier berganda dengan pendekatan Ordinary Least Square (OLS) merupakan metode yang digunakan untuk melihat hubungan atau pengaruh antara variabel dependen dan independen. Metode analisis yang digunakan dalam penelitian ini yaitu analisis regresi liniear berganda. Analisis regresi liniear berganda digunakan untuk mengetahui seberapa besar pengaruh variabel independen terhadap variabel dependen.

Dalam analisis regresi harus melalui beberapa pengujian diantaranya adalah uji hipotesis yang terdiri dari uji parsial (uji t), uji secara serentak (uji F) dan koefisien determinasi (R2), sedangkan uji asumsi klasik yang meliputi uji multikolinearitas, uji heteroskedastisitas,uji autokorelasi, uji normalitas.

Model yang digunakan dalam penelitian ini adalah model fungsi penyerapan tenaga kerja dengan 3 variabel independen dan 1 variabel dependen. Model matematis fungsi penyerapan tenaga kerja dalam penelitian ini adalah :

Log Penyerapan $=\alpha+\beta_{1} \log I+\beta_{2} G+\beta_{3} \log$ W.

$\begin{array}{ll}\text { Keterangan } & : \\ \text { Penyerapan } & : \text { Penyerapan TK Kab. Bogor } \\ \alpha & : \text { Parameter } \\ \text { Log I } & : \text { Log Variabel Investasi }\end{array}$

G

$\log \mathrm{W}$

: Laju Pertumbuhan Ekonomi

: Log Variabel Upah Kab. Bogor

Penelitian ini menggunakan Penyerapan Tenaga Kerja sebagai variabel dependen. Sebagai variabel yang dipengaruhi oleh variabel lain, variabel dependen ini dinyatakan dalam satuan banyaknya jumlah pekerja yang terserap pada kegiatan investasi yang terdata di Badan Penanaman Modal dan Pelayanan Terpadu Satu Pintu (BPMPTSP) Kabupaten Bogor dalam periode waktu satu tahun. Pada penyerapan tenaga kerja di Kabupaten Bogor diambil data sejumlah pekerja yang dipengaruhi jumlah investasi hingga tahun 2015. Variabel independen adalah variabel yang hanya bisa mempengaruhi tanpa bisa dipengaruhi oleh variabel lain. Berikut adalah variabel dependen yang digunakan untuk penelitian ini:

Investasi, sebagai variabel yang mempengaruhi penyerapan tenaga kerja, investasi ini dinyatakan dalam satuan rupiah. Diambil dari Penanaman Modal Asing (PMA) dan Penanaman Modal Dalam Negeri (PMDN) yang terdata oleh Badan Penanaman Modal dan Pelayanan Terpadu Satu Pintu (BPMPTSP) Kabupaten Bogor tahun 1986 sampai dengan tahun 2015. Peneliti menggunakan untuk melihat hubungan serta pengaruh kepada penyerapan tenaga kerja. Upah digunakan untuk melihat hubungan dan pengaruh terhadap penyerapan tenaga kerja di Kabupaten Bogor. Dinyatakan dalam satuan rupiah, upah di Kabupaten Bogor digunakan sebagai variabel independen pada penelitian ini. Pertumbuhan Ekonomi, yang sangat mempengaruhi penyerapan ini juga 
Dinoyatakan dalam satuan rupiah, upah di Kabupaten Bogor digunakan sebagai variabel independen pada penelitian ini. Pertumbuhan Ekonomi, yang sangat mempengaruhi penyerapan ini juga dinyatakan dalam persen. Artinya pertumbuhan dilihat setiap tahunya hingga tahun 2015 sebagai variabel independen.

\section{HASIL DAN PEMBAHASAN}

Berdasarkan hasil regresi, maka model ekonometrika yang dihasilkan sebagai berikut: $\log Y=\beta_{0}+\beta_{1} \log X_{1}+\beta_{2} X_{2}+\beta_{2} \log X_{3}$ $+\mu$.

$\log Y=6.569710-0.005426 \log I+0.195285$ $\mathrm{G}+0.137355 \log \mathrm{W}+\mu$

Dari estimasi model yang diperoleh berdasarkan hasil analisis regresi dapat diartikan melalui tabel 3. Sehingga apabila terjadi penurunan investasi sebesar $1 \%$, akan meningkatkan penyerapan tenaga kerja di Kabupaten Bogor sebesar 0.0054\% dengan asumsi ceteris paribus. Apabila terjadi peningkatan laju pertumbuhan ekonomi sebesar $1 \%$, akan meningkatkan penyerapan tenaga kerja di Kabupaten Bogor sebesar 0.19\% dengan asumsi ceteris paribus. Sedangkan apabila terjadi kenaikan Upah sebesar 1\%, akan meningkatkan penyerapan tenaga kerja di Kabupaten Bogor sebesar 0.13\% dengan asumsi ceteris paribusBerdasarkan perhitungan hasil regresi, menunjukkan nilai Probabilitas JarqueBera sebesar 0.114815 sedangkan taraf nyata yang digunakan dalam penelitian ini yaitu ( $\alpha=5 \%$ ), sehingga diperoleh nilai Probabilitas Jarque-Bera sebesar $0.114815>=5 \%(0,05)$, maka dapat disimpulkan bahwa data yang digunakan dalam penelitian ini terdistribusi secara normal. Berdasarkan uji multikolinieritas yang telah dilakukan terdapat nilai R2 majemuk > R2 parsial, yaitu (0.473936 > 0.219718, 0.191097, o.o83170). Mengetahui hasil regresi tersebut, maka dapat disimpulkan bahwa model regresi yang digunakan dalam penelitian ini terbebas dari masalah multikolinearitas.

Hasil uji heterokedastisitas menunjukkan bahwa model investasi sektor pertanian memiliki probabilitas $\mathrm{Obs}^{\star} \mathrm{R}$-square sebesar 0.3790 , dan taraf nyata dalam penelitian ini yaitu sebesar $\alpha=5 \%$. Artinya nilai probabilitas $\mathrm{Obs}^{\star} \mathrm{R}$-square $0.3790>$ dari taraf nyata $\alpha=0.05(5 \%)$. Oleh karena itu dapat disimpulkan bahwa pada model penyerapan tenaga kerja di Kabupaten Bogor bebas dari masalah heteroskedastisitas.

Berdasarkan hasil uji autokorelasi dapat diketahui bahwa nilai probabilitas Obs*Rsquared sebesar 0.0569, dan taraf nyata dalam penelitian ini sebesar $\alpha=5 \%$. Artinya nilai probabilitas Obs*R-squared sebesar $0.0569>$ dari taraf nyata yaitu sebesar $\alpha=5 \%$ (0.05). Berdasarkan hasil yang diperoleh, maka dapat disimpulkan bahwa model yang digunakan dalam penelitian ini tidak mengalami gejala autokorelasi atau terbebas dari masalah autokorelasi. Hasil regresi menunjukkan bahwa nilai dari R2 adalah sebesar 0.473936, yang berarti penyerapan tenaga kerja di Kabupaten Bogor dapat dijelaskan oleh variasi model dari investasi, laju pertumbuhan ekonomi, dan upah sebesar 47,39\% dan sisanya sebesar 52,61\% dijelaskan oleh variabelvariabel lain di luar model.

Berdasarkan hasil regresi yang diperoleh yaitu nilai F-hitung $=7.807894>$ F-tabel = 2,98, sehingga hipotesis nol (Ho) ditolak dan Hipotesis alternatif 
(Ha) diterima. Sehingga hasil dari uji sama berpengaruh secara nyata F menyatakan bahwa variabel independen terhadap variabel dependen penyerapan yaitu investasi, laju pertumbuhan tenaga kerja di kabupaten Bogor.. ekonomi, dan upah secara bersama-

Tabel 3. Hasil Ujit - Statistik

\begin{tabular}{lllll}
\hline Variabel & t-statistik & Probabilitas & t-tabel & Kesimpulan \\
\hline Investasi & -0.257086 & 0.7991 & 1.70562 & $\begin{array}{l}\text { Tidak signifikan pada } \alpha= \\
5 \%\end{array}$ \\
LajuPertumbuhan ekonomi & $\mathbf{2 . 7 3 5 0 1 8}$ & 0.0111 & $\mathbf{1 . 7 0 5 6 2}$ & $\begin{array}{l}\text { Signifikan pada } \alpha=5 \% \\
\text { Upah }\end{array}$ \\
\hline
\end{tabular}

Sumber : Data Penelitian diolah

\section{SIMPULAN}

Berdasarkan hasil data yang telah diolah menggunakan regresi mengenai pengaruh investasi, laju pertumbuhan ekonomi, dan upah terhadap penyerapan tenaga kerja di Kabupaten Bogor, dapat ditarik kesimpulan Investasi tidak berpengaruh signifikan terhadap penyerapan tenaga kerja di Kabupaten Bogor. Laju pertumbuhan ekonomi berpengaruh positif dan signifikan terhadap penyerapan tenaga kerja di Kabupaten Bogor. Upah berpengaruh positif dan signifikan terhadap penyerapan tenaga kerja di Kabupaten Bogor. Secara simultan investasi, laju pertumbuhan ekonomi, dan upah menunjukkan pengaruh yang signifikan terhadap penyerapan tenaga kerja di Kabupaten Bogor.

\section{DAFTAR PUSTAKA}

Badan Penanaman Modal dan Pelayanan Terpadu Satu Pintu Kabupaten Bogor. 2015. Realisasi Penanaman

Modal Asing dan Dalam Negeri tahun 2009 - 2015. Kabupaten Bogor: BPMPTSP.
Badan Pusat Statistik Indonesia. 2015. Realisasi Penanaman Modal Asing dan Dalam Negeri Kabupaten Bogor Tahun 2015. Jakarta: Badan Pusat Statistik.

Badan Koordinasi Penanaman Modal Indonesia. 2015. Realisasi Penanaman Modal Asing dan Dalam Negeri Indonesia Tahun 2010 - 2014. Jakarta: BKPM Pusat.

Badan Koordinasi Penanaman Modal Provinsi Jawa Barat. 2015. Realisasi Penanaman Modal Kabupaten/Kota Provinsi Jawa Barat 2015. Jawa Barat: BKPM.

Djojohadikusumo, Sumitro. 1993. Perkembangan Pemikiran Ekonomi, Pertumbuhan dan Ekonomi Pembangunan. Jakarta: Pustaka LP3ES Indonesia.

Eka Putra, Riky. 2012. Pengaruh Nilai Investasi, Nilai Upah, dan Nilai Produksi Terhadap Penyerapan Tenaga Kerja Pada Industri Mebel di Kecamatan Pedurungan Kota Semarang. EDAJ 1 (2) (2012). Semarang: Univesrsitas Negeri Semarang.

---------. 1999. Pengantar Teori Makro Ekonomi. Jakarta: Grafindo Persada

Suryana. 200o. Ekonomi Pembangunan: Problematika dan pendekatan. Jakarta: Salemba Empat.

Widarjono, Agus. 2009. Ekonometrika, Pengantar dan Aplikasinya.Yogyakarta: Ekonisi 